\title{
Needs Analysis of the Students of the 3d Class of Junior High School
}

\author{
Evanthia Avgerou ${ }^{1}$ \\ ${ }^{1}$ English language teacher (M.Ed. in TESOL), $1^{\text {st }}$ Junior High School of Aigio, Greece \\ Correspondence: Evanthia Avgerou, English language teacher (M.Ed. in TESOL), $1^{\text {st }}$ Junior High School of Aigio, \\ Greece. E-mail: eviavg74@gmail.com
}

Received: June 1, 2015

Accepted: June 23, 2016

Online Published: June 24, 2016

doi:10.5430/elr.v5n2p45

URL: http://dx.doi.org/10.5430/elr.v5n2p45

\begin{abstract}
This paper seeks to explore whether English language learning is viewed as an accumulation of language skills merely for the acquisition of a foreign language certificate, which is the commonly held view regarding English language instruction in Greece, or Junior High School learners would wish to have a more holistic view of foreign language learning in the context of a challenging multicultural environment. The research was conducted in a Greek state school of a rural area and renders significant results as to the shift of focus from traditional views regarding English language teaching in Greece to what contemporary teenagers would like to accomplish through foreign language instruction provided by the state. The paper ultimately identifies the needs of Junior High School learners regarding English language instruction through the use of a questionnaire and discusses the implications of the findings for the amendment of the existing teaching materials to the benefit of the learners.
\end{abstract}

Keywords: State school, Language instruction, Language skills, Multicultural environment, Teaching materials

\section{Introduction}

\subsection{Prevailing Mentality among Greek Learners regarding English Language Instruction}

There has been a commonly held view among the interested parties -Greek foreign language learners and their parents- that foreign language instruction is of lesser importance in Greek state schools since most learners receive foreign language lessons in private institutes called 'frontisteria' in Greek. Those private institutes are widely acknowledged for offering specialised language instruction to the majority of learners aged 8 and above, preparing them for language exams organised by universities of international renown and enable Greek learners to obtain a language certificate (Mattheoudakis \& Alexiou, 2009).

In contrast, state schools provide fewer teaching hours and less intensive courses than private language institutes and are 'plagued' by the following issues: a) tuition is not focused on language certification, b) the groups of learners are very large and mixed-ability ones, c) teachers are usually unmotivated and d) state schools do not provide language certificates (Angouri, Mattheoudakis \& Zigrika, 2010).

\subsection{Research Questions}

Against this background, English language instruction provided by the state is strongly devalued. The present paper aspires to fill a void in current research in Greek state-provided language education by exploring the following issues:

- What is the Greek learners' attitude towards state-provided language instruction?

- What are the learners' actual needs and expectations from foreign language instruction at school?

- How can the teaching materials used in state schools be amended in order to meet those needs and upgrade state-provided language instruction?

\subsection{Brief Literature Review of Needs Analysis}

As far as English language teaching is concerned, there has been an attempt to track what Gardner and Tremblay (1994 in Angouri, Mattheoudakis \& Zigrika, 2010:180) have called 'a motivational renaissance'. The term implies that 'the classroom environment and, more specifically, the contextual surroundings of action', according to Dörnyei (2003 in Angouri, Mattheoudakis \& Zigrika, 2010:180) have had a much stronger motivational impact in recent years than what had been suggested before. 
Designing a questionnaire in order to investigate learners' needs is an innovative procedure for the Greek educational system since in most cases English language teaching has been regarded as a 'neutral transfer of skills, knowledge or competences' (Auerbach, 1995:9). With the implementation of pilot programmes the learners are invited 'to critically examine [ the existing order] and become active in shaping their own rules in it' (Auerbach, 1995:15).

There has been a transfer of focus recently from 'product oriented needs' that is, language proficiency needs or specific purposes needs that can be regarded as 'objective needs' (Brindley, 1989:63 in Manolopoulou-Sergi, 2004:89) and deal with learners having to use the language accurately in particular communication instances to 'process oriented needs' or otherwise 'subjective needs' ( Brindley, 1989:63 in Manolopoulou-Sergi, 2004:89). These needs cater more for learners' individual differences and interests. The concept of catering for individualised learner needs instead of focusing on a 'fairly traditional, form-focused L2 education' (Davies, 2006:9) has been of paramount importance in designing the questionnaire used in the present research.

\section{Method}

\subsection{Description of Teaching Context}

The questionnaire was answered by 22 learners (12 girls and 10 boys) in the $3 \mathrm{~d}$ class of the $1^{\text {st }}$ Junior High School in Aigio, a rural area of Greece, in which the teacher is currently employed. The school has been chosen for the pilot implementation of the project 'New School-School of the $21^{\text {st }}$ century'. For this reason, the findings of the questionnaire might be of particular interest in order to redesign the existing curriculum, bearing in mind the learners' needs instead of following a strict syllabus imposed by the Ministry of Education.

\subsection{Description and Rationale of the Questionnaire}

The questionnaire consists of six parts. Part A consists of general statements, where the participants are invited to identify the reason they learn English at school, to specify the main problems of the teaching materials they are currently using and the main problems in their English language class as a learning environment.

This introductory section has been used as a warm-up stage in order to make learners aware that they are regarded as 'valued participants in the classroom' and give the teacher a clue as to what extent 'certain beliefs about language and learning may need to be channelled or challenged with suitable teaching intervention challenges'( Cotterall, 1999; Kumaradivelu, 1991 in Davies, 2006:5).

The following four parts ( Part B, Part C, Part D, Part E) refer to Listening, Speaking, Reading and Writing skills respectively. The participants are called to specify what they need each of these skills for, allowing room to investigate their wishes 'to use these skills for some purpose beyond the learning environment itself' (Nunan, 1988:42 in Fatihi, 2003:48). The participants are also called to identify the actual ways in which skills are performed in their language classroom, specific problems they may be encountering while carrying out tasks in each of these skills as well as suggest some ways in which the performance of each task could be improved.

The last part of the questionnaire involves asking the respondents' opinion about certain issues that have to do with their 'objective needs' (language proficiency) and the possibility to obtain a language certificate from school as well as their 'subjective needs' (confidence, attitudes, expectations) (Brindley, 1989 in Fatihi, 2003:55). The last part also aims at exploring the extent to which the learners themselves could participate in the shaping of a 'learner-centered system' (Nunan, 1988:42 in Fatihi, 2003:48).

The questions were mostly close-ended in order to produce ' more uniform answers' (Taylor-Powell, 1998:5) ( Q A1,2,3 B 5,7,8 C 9,10, 12 D 13, 14, 17 Appendix I) . There were also ordered choices 'never', 'rarely', 'sometimes', often', 'always' in order to evaluate attitudes (Taylor-Powell, 1998) ( Q 11,15, 19 Appendix I). Another category was 'YES-NO' questions but with a third option provided 'Don't know' (DN) in order to avoid bias (Q 20-25 Appendix I) as well as 'filter' or 'screen' questions that did not apply to all respondents (Taylor-Powell, 1998) ( Q 4,6 Appendix I). 


\section{Presentation of Main Results}

Table 1. English language learning at school

\begin{tabular}{ll}
\hline Reasons for learning English at school & $\%$ \\
\hline Obligatory in the school curriculum & 18 \\
To get a language certificate & 22 \\
To be able to improve knowledge acquired in frontisteria & 22 \\
For no obvious reason & 36
\end{tabular}

In section A which included general statements in order to check the respondents' attitudes about their current learning situation, the majority of the participants (36\%) think that they are taught English at school for no obvious reason. This result bears implications about the role that English language learning plays in the Greek educational system. English language learners have to acquire a language certificate after completing an excruciating set of exams, an opportunity provided to them only by private institutes, otherwise 'frontisteria'. This is why students see 'no obvious reason' for learning English at school.

Table 2. Listening skills in English

\begin{tabular}{ll}
\hline Usefulness of good mastery of listening skills in English & $\%$ \\
\hline Understand native speakers when travelling abroad & 82 \\
Be able to understand TV programmes without subtitles & 46 \\
Understand the lyrics of English songs & 42 \\
Be able to pass the listening part of an exam & 50
\end{tabular}

As far as listening skills are concerned, the participants' answers focused on practical issues of language use, for example, being able to understand native speakers when travelling abroad (82\%) and being able to pass the listening part of an exam (50\%).

Table 3. Speaking skills in English

Usefulness of good mastery of speaking skills in English $\%$

Be able to pass the speaking part of an exam 59

Communicate effectively with native speakers when travelling abroad $\quad 91$

Respond to questions in a job interview abroad 64

Attend a foreign university $\quad 59$

Speak with relatives who live abroad when they visit Greece 32

As far as speaking is concerned, the vast majority of the respondents (91\%) pointed out that they need to develop their speaking skills in order to be able to communicate with native speakers when travelling abroad and for more practical reasons again, that is, to be able to pass the speaking part of an exam (59\%) or to be able to attend a foreign university (59\%).

Table 4. Writing skills in English

\begin{tabular}{lc}
\hline Usefulness of good mastery of writing skills in English & $\%$ \\
\hline Comment on Facebook or other discussion forums on the Internet & 18 \\
Exchange e-mails or text messages with friends or relatives who live abroad & 36 \\
Apply for a course in a university abroad & 73 \\
Apply for a job abroad & 55 \\
Pass the writing part in an exam & 55
\end{tabular}


Finally, findings concerning writing skills are not surprising, considering the general viewing of language skills by Greek Junior High School students. 73\% need to have good writing skills in order to apply for a course in a foreign university and 55\% in order to apply for a job abroad or pass the writing part in an exam.

Table 5. Improvement of language proficiency in the state school English class.

Ways to improve language proficiency in the state school English class

Use authentic recordings for listening $\%$

Be actively engaged in a project with the bibliography exclusively in English 73

Initiate class discussions in English 59

Read books in English

It is also remarkable how the learners select ways to improve their language proficiency in the state school English class: $73 \%$ would like to use authentic recordings for listening and 59\% would like to carry out a research project with the bibliography exclusively in English. A remarkable percentage of 50\% stated that they would initiate class discussions in English on issues of their choice and $45 \%$ of learners stated that they would be willing to read books in English in order to improve their reading skills when, at the same time, the majority of the respondents seem unwilling or unable to tackle reading texts in the school textbooks.

Table 6. Improvement of English outside the class

\begin{tabular}{ll}
\hline Ways to improve English outside the class & $\%$ \\
\hline Participate in student exchange programs & 59 \\
Perform a theatrical play in English & 45
\end{tabular}

In conclusion, there seems to be a shift of interest towards more genuine communicative activities in the English language class, such as participating in student exchange programs or performing a theatrical play entirely in English . A need for learners 'to bring their own agendas in the language lessons they attend' (Nunan, 1989) is clearly observed.

\section{Discussion}

\subsection{The 'Utilitarian' Nature of English Language Learning}

In analysing the findings of the research, there seem to be two main trends regarding the approach of Greek learners to English language instruction.

The first trend could be described as the 'utilitarian' one. English language learning is 'inherently ideological in nature', has 'significant implications for learners' socioeconomic roles' and is viewed as a 'neutral transfer of skills, knowledge and competencies' (Auerbach, 1995:9). The above findings show the way in which the Greek society views English language learning, that is, as solely leading to the acquisition of a language certificate or as a means to pursue further studies abroad. In other words, 'language skills are needed in order to survive in an English-dominant society' (Richards, 2001:55).

The importance of English as a lingua franca in a multicultural globalised working environment is generally agreed upon, according to the findings of the research. Despite the fact that 'the linguistic ecology of modern workplaces is dynamic, rich and diverse' (Louhiala-Salminen \& Kankaanranta, 2005) and by no means can it be considered a monolingual one, English is profoundly useful in occupying a prestigious post in the job market.

The certified knowledge of English as a qualification in the job market is dominant in the Greek culture as well. Given the high unemployment rates in a markedly competitive society, Greek learners consider it of the utmost importance to receive an advanced certificate in English that will offer them a strong handicap against their peers and will protect them from 'menial' jobs in a relentless job market. 


\subsection{The 'Communicative' Nature of English Language Learning}

The second trend in English language learning that the present research has shown is the 'communicative' one.

Greek learners view themselves as citizens in a globalised environment and wish to get acquainted with cultural elements of English-speaking countries and not just receive a 'traditional, form-focused L2 education' (Davies, 2006:7).

Therefore, it is safe to assume that learners, even if they unknowingly and subconsciously resist the 'utilitarian rationale' ( Nunan, 1988:42 in Fatihi, 2003:48) regarding English language learning, still wish to use their skills for real-life communication situations and welcome innovative ways that would allow them to express their own meanings in interactions with native speakers.

The majority of learners seem to understand that the world has greatly changed and, as research by Warschauer (2000) supports, in a globalised world English is not the language of native speakers any more but a language shared among various groups of non-native speakers with different socio-cultural and socio-economic characteristics. English has escaped the strict confines of the English-speaking world and has become an international language including business entrepreneurship, technological advancement, world travel, sport and music, as Lamb (2004) declares.

This different viewing of English language instruction shifts focus from the traditional approach that sees language mainly as a tool in the professional realm towards a more communicative approach that provides the instructor with information about the learner and the skills he or she needs in order to carry out real-world communicative activities (Nunan, 1988).

The communicative model gives learners the chance to engage in authentic communicative activities bearing in mind their unique potential and personal differences. Since communication exchanges involve both native speaker-non-native speaker and non-native speaker-non-native speaker interactions as Alptekin (2002) maintains, it is essential to design teaching materials that will take into consideration these differences and give the opportunity to non-native speakers to be actively engaged in genuine communicative instances and reach their desired language standards (Andreou \& Galantomos, 2009).

The successful language user is no longer a monolingual-native one, but he or she has the ability to overcome language barriers and operate successfully with other users from different cultural backgrounds in cross-cultural settings (Andreou \& Galantomos, 2009). In other words, the successful English language user 'is expected to exhibit both global language awareness and local appropriation' (Kramsch \& Sullivan, 1996 in Andreou \& Galantomos, 2009: 205). Those skills will enable the language user to communicate in an effective manner both at a national and international level.

Finally, as Widdowson (1998) maintains, teaching materials should include appropriate discourse samples from a variety of native and non-native speaker interactions in order to offer learners the opportunity to be exposed to different communicative instances performed by other language users with various linguistic and cultural profiles as well as different learning objectives.

\section{Concluding Remarks}

The present research, although restricted to a very small sample of Greek High School learners, has indicated that certain attitudes regarding English language instruction in Greece are deeply rooted in large strata of the Greek society. Greek learners, striving to acquire more vocational qualifications and aspiring to expand their professional horizons abroad in the middle of an ongoing financial crisis, largely view English language instruction as a necessary evil that will add more points to their curriculum vitae through a prestigious language certificate.

Nevertheless, there are traces of a shift of focus from the 'utilitarian' viewing of English language learning to a more 'communicative' one that is more in tune with the globalised environment that young learners live in. English is an integral part of learners' reality and is omnipresent: from social media to interactive games, music, satellite channels and foreign websites. Therefore, young learners seem to seek-often unbeknownst to them- more and more instances of genuine communication in a virtual or real environment, even if it is not the immaculate linguistic environment of native speakers.

According to the research findings, Greek learners seem to pursue instances of English language use in the real world so as to feel more confident to act as equal members of the 'global village', where intellectual capacities and formal qualifications have to pair with problem-solving abilities in an environment where English is used as a lingua franca by people from all walks of life. 


\section{References}

Alptekin, C. (2002). Towards intercultural communicative competence in ELT. ELT Journal, 56(1), 57-63. http://dx.doi.org/10.1093/elt/56.1.57

Andreou, G \& Galantomos, I. (2009). The native Speaker Ideal in Foreign Language Teaching. Electronic Journal of Foreign Language Teaching, 6(2), 200-208. Retrieved from http://e-flt.nus.edu.sg/v6n22009/andreou.pdf

Angouri, J., Mattheoudakis, M. \& Zigrika, M. (2010). Then how will they get 'the much wanted paper?' A multifaceted study of English as a foreign language in Greece, GALA, 179-197. Retrieved from http://www.enl.auth.gr/gala/14th/englishArticles_en.htm

Auerbach, E.R. (1995). The politics of the ESL classroom: Issues of power in pedagogical choices. In J. Tollefson (Ed.), Power and Inequality in Language Education (pp. 9-33). New York: Cambridge University Press.

Block, D. (1991). Some thoughts on DIY materials design. ELT Journal, 45(3), 211-217. http://dx.doi.org/10.1093/elt/45.3.211

Brindley, G. (1989). The role of needs analysis in adult ESL programme design. In R.K. Johnson (Ed.), The second language curriculum (pp. 63-78). New York: Cambridge University Press. http://dx.doi.org/10.1017/CBO9781139524520.007

Cotterall, S. (1999). Key variables in language learning: What do learners believe about them. Personal communication, System, 27(4), 473-492. http://dx.doi.org/10.1016/s0346-251x(99)00047-0

Davies, A. (2006). What do learners really want from their EFL course? ELT Journal, 60(1), 3-12. http://dx.doi.org/10.1093/elt/ccio 74

Dörnyei Z. (2003). Attitudes, orientations, and motivations in language learning: Advances in theory, research and applications. Language Learning, 53 (Suppl 1), 3-32. http://dx.doi.org/10.1111/1467-9922.53222

Fatihi, R.A. (2003). The Role of Needs Analysis in ESL Program Design. South Asian Language Review, 13(1/2), 39-59. Retrieved from http://www.geocities.ws/southasianlanguagereview/SecondLanguage/fatihi.pdf

Gardner R.C. \& Tremblay P.F. (1994). On motivation, research agendas, and theoretical frameworks. Modern language Journal, 78(3), 524-527. http://dx.doi.org/10.1111/j.1540-4781.1994.tb02050.x

Kramsch, C. \& Sullivan, P. (1996). Appropriate pedagogy, ELT Journal, 50(3), 199-212. http://dx.doi.org/10.1093/elt/50.3.199

Kumaradivelu, B. (1991). Language-learning tasks: teacher intention and learner interpretation. ELT Journal, 45(2), 98-107. http://dx.doi.org/10.1093/elt/45.2.98

Lamb, M. (2004). Integrative motivation in a globalising world. System, 32, 3-19. http://dx.doi.org/10.1016/j.system.2003.04.002

Louhiala-Salminen, L \& Kankaaranta, A. (2005). Hello, Monika, kindly change your arrangements: business genres in a state of flux. In P. Gillaerts and M. Gotti (Eds), Genre variation in business letters: Linguistic insights (pp. 55-84). Bern, Switzerland: Peter Lang.

Manolopoulou-Sergi, E. (2004). Needs Analysis. In Ayakli, C., Karavas, K., Manolopoulou-Sergi E. \& Spinthourakis J.A.. Course Design and Evaluation (pp.81-124). Patras: Hellenic Open University.

Mattheoudakis M. \& Alexiou, T. (2009). Early foreign language instruction in Greece: socioeconomic factors and their effect on young learners' language development. In M. Nikolov (Ed), Contextualising the Age Factor (pp. 227-251). Clevendon: Multilingual Matters. http://dx.doi.org/10.1515/9783110218282.227

Nunan, D. (1988). Syllabus Design. Oxford: OUP.

Nunan, D. (1989). Hidden agendas: The role of the learner in programme implementation. In R.K. Johnson (Ed.), The second language curriculum (pp.176-187). New York: Cambridge University Press. http://dx.doi.org/10.1017/CBO9781139524520.013

Richards, J, K. (2001). Curriculum Development in Language Teaching. New York, NY: Cambridge University Press. http://dx.doi.org/10.1017/CBO9780511667220

Taylor-Powell, E. (1998). Questionnaire design: Asking questions with a purpose. Madison, WI: Cooperative Extension Publications. 
Warschauer, M. (2000). The changing global economy and the future of English teaching. TESOL Quarterly, 34, 511-535. http://dx.doi.org/10.2307/3587741

Widdowson, H.G. (1998). Context, community and authentic language. TESOL Quarterly, 32(4), 705-716. http://dx.doi.org/10.2307/3588001

\section{APPENDIX I NEEDS ANALYSIS QUESTIONNAIRE}

Needs Analysis of English as a foreign language in the framework of the project 'NEW SCHOOL (School of the $21^{\text {st }}$ century) -Pilot Implementation

This questionnaire is part of a project being carried out by English teachers in the framework of pilot implementation of 'NEW SCHOOL (School of the $21^{\text {st }}$ century) in order to investigate the needs of Junior High School students regarding English as a foreign language with the aim to supplement existing teaching materials or substitute them altogether with materials designed by the teacher to cover the increasing students' needs in the school of the $21^{\text {st }}$ century. It would be appreciated if you could complete this questionnaire which should take approximately 30 minutes. Please complete this questionnaire bearing in mind your existing learning situation.

\section{A. General statements}

1. Please circle one of the following reasons for learning English at school.

a. Obligatory in the school curriculum

b. To get a language certificate

c. To be able to improve knowledge of English acquired in private schools (frontisteria)

d. For no obvious reason

2. What are the main problems of the teaching materials you are currently using? Please circle the options that apply to you.

a. Vocabulary too difficult to understand

b. Grammar too difficult to understand

c. Tasks are boring -have nothing to do with the students' reality

d. Don't give enough clues for life in English-speaking countries

e. Task instructions are too difficult to understand

3. What are the main problems in your English language class? Please circle the options that apply to you.

a. Too many students in the class

b. Students not at the same level of language proficiency

c. No equipment available for English language teaching

d. Too many naughty students who disrupt the lesson

e. No books distributed by the Ministry of Education

f. Lack of interest in the lesson because English is considered less important than other subjects

4. How would you describe your English language teacher? Circle the option that most applies to you. ( $P=$ poor, $A=$ Average, $, G=G o o d, ~ V G=$ very good, $E=$ excellent)

$\begin{array}{llllll}\text { a.Teacher's language proficiency } & P & A & G & \text { VG } & E\end{array}$

b.Teacher's ability to explain tasks clearly $\quad P \quad$ A $\quad$ G $\quad$ VG $E$

c.Teacher is able to make the lesson more interesting with activities outside the coursebook YES NO 
- If you answered YES tick the ways your teacher uses to motivate you

$\square$ shows authentic videos about the foreign culture

$\square$ uses interactive whiteboard exercises

$\square$ involves you in projects that offer you a clear picture of life and culture in the English-speaking countries

$\square$ organises student exchange programmes

$\square$ invites native speakers to talk to you and help you practise the language

\section{For questions d -g please underline one of the options}

d. Teacher is willing to talk to students and explain their mistakes to them

$$
\text { never rarely sometimes often always }
$$

e. Teacher is able to discipline naughty students

never rarely sometimes often always

f. Teacher is polite to students never rarely sometimes often always

g. Teacher encourages students never rarely sometimes often always

\section{B. Listening Skills}

5. What do you need listening skills for? Please circle the options that apply to you.

a. To be able to understand native speakers when travelling abroad

b. To be able to understand TV programmes without subtitles

c. To be able to understand the lyrics of my favourite songs

d. To be able to pass the listening part of an exam

\section{In what ways is listening provided in your English language class? Please circle the options that apply to you. \\ a. Listening to non-authentic talks from class CDs. \\ b. Listening to your teacher reading the listening tapescript aloud for you \\ c. Listening to authentic talks from various sources YES NO}

- If you answered YES please specify:

$\square$ authentic talks from radio programmes

$\square$ authentic talks from TV programmes

$\square$ authentic talks from videos and/or audio files from a computer

7. What are the main problems that you have during listening? Please circle the options that apply to you.

a. Don't understand the different accents of the speakers

b. Being unable to spot the information needed to complete the listening exercises

c. Speakers speak too quickly

d. Bad recording quality of the tapes or CDs

e. Outside noise 
f. Bad acoustics in the classroom

g. Listening twice is not enough; I need to listen three times

8. In which of the following ways do you think that practice of the listening skill could be improved in your English language class? Tick the options that apply to you.

$\square$ Have a special room for listening with headphones so as to minimise outside noise

$\square$ Have the listening heard three times instead of two

$\square$ Use authentic materials (foreign films, TV/ radio programmes, songs) and organise the listening tasks around them

\section{Speaking Skills}

9. What do you need speaking skills in the foreign language for? Circle the options that apply to you.

a. To be able to pass the speaking part in an exam

b. To be able to communicate with native speakers when travelling abroad

c. To be able to answer questions in a job interview abroad

d. To be able to attend a foreign university

e. To be able to speak with my relatives who live abroad when they visit Greece

10. How is speaking carried out in your English language class? Please tick the options that apply to you. $\square$ Through role-play whenever there is a relevant task in the coursebook

$\square$ Through free class discussions on topics existing in the coursebook

$\square$ With the teacher asking specific questions on specific topics as a follow-up of other activities in the coursebook

$\square$ There is no speaking practice in the language classroom at all.

11. What are the main problems with the practice of the speaking skill in your English language class? Please circle the option that applies most to you.

a. Only few students participate in class discussions, the others make noise.

never rarely sometimes often always

b. Most students are too shy to talk.

never rarely sometimes often always

c. Most students don't know the vocabulary necessary to carry out discussions on certain topics.

never rarely sometimes often always

d. Most students think they get enough speaking practice in frontisteria and don't care to participate in class discussions

never rarely sometimes often always

e. A lot of students find speaking topics boring

never rarely sometimes often always

f. Some students make fun of other students' mistakes during speaking

never rarely sometimes often always 
12. How do you think that practice of the speaking skill could be improved in your English language class? Tick the options that apply to you.

$\square$ Have class discussions outside the coursebook on topics the students would like to talk about

$\square$ Organise speaking forums through Skype with students from other countries

$\square$ Organise student exchange programmes with students from English speaking countries over Christmas, Easter or summer holidays

$\square$ Have discussions in class that are likely to occur in real life, such as a job interview or applying for a course in a foreign university

$\square$ Perform a theatrical play in English at the end of the school year.

\section{Reading Skills}

\section{What do you need reading skills for? Circle the options that apply to you.}

a. To be able to read foreign newspapers, magazines

b. To be able to read comments on Facebook or other discussion forums on the Internet

c. To pass the reading part in an exam for a language certificate

d. Because I need good reading skills to be admitted in a foreign university

14. What are the main reading skills you are taught in your English language class? Please tick the options that apply to you.

$\square$ To answer general comprehension questions from the text

$\square$ To answer multiple-choice questions from the text

$\square$ To be able to say what the text is about

$\square$ To put sentences that have been removed from the text back into it

$\square$ To rearrange paragraphs in a text

15. What are the characteristics of the reading texts that appear in your class textbook? Circle the option that applies most to you each time.

a. Texts are too long. never rarely sometimes often always

b. The vocabulary in the texts is too difficult. never rarely sometimes often always

c. The syntax is too difficult (long sentences). never rarely sometimes often always

d. Texts are mostly about scientific topics. never rarely sometimes often always

e. Texts are mostly about foreign culture topics never rarely sometimes often always

f. Texts are mostly about school life topics. never rarely sometimes often always

g. Mostly literary texts never rarely sometimes often always

16. Would the introduction of the following features improve reading skills in your English language class? Circle the option that applies most to you each time.

(DN=Don't know)

a. Borrowing books from the school library to read during your holidays.

YES NO DN

b. Be allowed to follow discussion forums on the Internet during class time.

YES NO DN 
c. Carry out a research project in English for which you get extra marks with the help of your teacher. The whole bibliography will be in English.

YES NO DN

\section{E. Writing Skills}

17. What do you need writing skills for? Tick the options that apply to you.

$\square$ To comment on Facebook or other discussion forums on the Internet.

$\square T o$ exchange e-mails or text messages with my friends and relatives who live abroad.

$\square$ To apply for a course in a foreign university in the future.

$\square$ To apply for a job abroad.

$\square$ To pass the writing part in an exam.

18. What are the main writing tasks that you are assigned in your English language class? Tick the options that apply to you.

$\square$ E-mails $\square$ Informal letters

口Narratives

$\square$ Stories

$\square$ Reports

$\square$ Reviews

$\square$ Formal letters

19. What are the main problems that you have with writing? Circle the option that most applies to you.
a. Understanding task instructions
never rarely sometimes often always
b. Organising ideas into paragraphs
never rarely sometimes often always
c. Not having enough ideas
never rarely sometimes often always
d. Using the appropriate vocabulary
never rarely sometimes often always
e. Using the appropriate register (formal/informal) never rarely sometimes often always
f. Expressing your ideas clearly
never rarely sometimes often always
g. Problems with grammar never rarely sometimes often always
h. Problems with syntax (constructing sentences) never rarely sometimes often always
i. Problems with spelling, punctuation
never rarely sometimes often always

20. Which of the following do you think would be useful in improving your writing skills? Circle one of the options ( DN= Don't know)

a. Get detailed comments at the end of your writing task analysing your mistakes.

\section{YES NO DN}

b. Have your written assignments exchanged with those of other students, correct each other's work and comment on each other's mistakes.

\section{YES NO DN}

c. Have a model draft given to you by your teacher after your work has been corrected to compare it with what you have written.

\section{YES NO DN}

$$
\text { g. Organise writing workshops in class and carry out assignments in groups. }
$$


YES NO DN

\section{F. Further suggestions}

We would like your opinion to some of our ideas for the improvement of English language teaching in Greek state schools. For each of the questions 21-25 below, please circle the answer that most applies to you. (DN=Don't know)

21. Do you think that being prepared to get a certificate in English (Kratiko Pistopioitiko Glossomathias) from the state school would make you more interested in learning English at school?

YES NO DN

22. Would you be willing to be part of a group preparing for the Kratiko Pistopioitiko Glossomathias in your school or another school in your area?

YES NO DN

23. Would you like to take part in student exchange programmes with students from English speaking countries in order to improve your language skills?

YES NO DN

24. Would you like to invite someone in your school to give you information in English about studies or job opportunities abroad?

\section{YES NO DN}

25. Would you like to be part of a team of teachers and language experts that would design new teaching materials for your school with your own needs and interests in mind?

YES NO DN

\section{THANK YOU FOR YOUR HELP!}

